OPEN ACCESS

Approved by:

Frontiers Editorial Office

Frontiers Media SA, Switzerland

${ }^{*}$ Correspondence:

Frontiers Production Office production.office@frontiersin.org

Specialty section:

This article was submitted to

Public Mental Health,

a section of the journal

Frontiers in Psychiatry

Received: 29 January 2021 Accepted: 01 February 2021 Published: 19 February 2021

Citation:

Frontiers Production Office (2021)

Erratum: Acceleration of Anxiety, Depression, and Suicide: Secondary

Effects of Economic Disruption

Related to COVID-19.

Front. Psychiatry 12:660659.

doi: 10.3389/fpsyt.2021.660659

\section{Erratum: Acceleration of Anxiety, Depression, and Suicide: Secondary Effects of Economic Disruption Related to COVID-19}

\author{
Frontiers Production Office* \\ Frontiers Media SA, Lausanne, Switzerland
}

Keywords: COVID-19, economy, suicide, depression, national income loss, unemployment, recession, Great Recession

\section{An Erratum on}

Acceleration of Anxiety, Depression, and Suicide: Secondary Effects of Economic Disruption Related to COVID-19

by Brenner, M. H., and Bhugra, D. (2020). Front. Psychiatry 11:592467. doi: $10.3389 /$ fpsyt.2020.592467

Due to a production error, there was an error in the affiliations. The affiliations for M. Harvey Brenner should read: 1. Johns Hopkins University Bloomberg School of Public Health, Health Policy and Management, Baltimore, MD, United States. 2. University of North Texas Health Science Center, Fort Worth, TX, United States. 3. Medizinische Hochschule Hannover, Hanover, Germany. The affiliation for Dinesh Bhugra should read: 4. King's College London, London, United Kingdom. The publisher apologizes for this mistake.

The original article has been updated.

Copyright ( 2021 Frontiers Production Office. This is an open-access article distributed under the terms of the Creative Commons Attribution License (CC BY). The use, distribution or reproduction in other forums is permitted, provided the original author(s) and the copyright owner(s) are credited and that the original publication in this journal is cited, in accordance with accepted academic practice. No use, distribution or reproduction is permitted which does not comply with these terms. 